\title{
Hierarchical network structure as seen in container shipping liner services in the Caribbean Basin
}

La structure hiérarchique de type réseau vue dans le transport des conteneurs dans le Bassin des Caraibes

\section{Robert J. McCalla}

\section{CpenEdition \\ Journals}

Electronic version

URL: http://journals.openedition.org/belgeo/13474

DOI: $10.4000 /$ belgeo.13474

ISSN: 2294-9135

Publisher:

National Committee of Geography of Belgium, Société Royale Belge de Géographie

Printed version

Date of publication: 31 December 2004

Number of pages: $407-418$

ISSN: 1377-2368

Electronic reference

Robert J. McCalla, « Hierarchical network structure as seen in container shipping liner services in the Caribbean Basin », Belgeo [Online], 4 | 2004, Online since 15 September 2013, connection on 20 April 2019. URL : http://journals.openedition.org/belgeo/13474 ; DOI : 10.4000/belgeo.13474

This text was automatically generated on 20 April 2019.

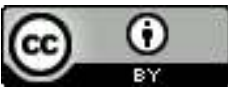

Belgeo est mis à disposition selon les termes de la licence Creative Commons Attribution 4.0 International. 


\title{
Hierarchical network structure as seen in container shipping liner services in the Caribbean Basin
}

\author{
La structure hiérarchique de type réseau vue dans le transport des conteneurs \\ dans le Bassin des Caraibes
}

Robert J. McCalla

\section{Introduction}

1 The study of geography is replete with hierarchical relationships defined not only by function but also by form. Hierarchy is defined as "a structure in which different parts are linked by predominance relationships" (Medda, Nijkamp and Rietveld, 2000). Christaller's central place theory is quintessentially hierarchical in both concept and form. Similarly, administration and management functions take on spatial hierarchical dimensions; for example, the spatial organization of church administration, or service territories of insurance companies or book publishers which have international, national, regional and local offices. In nature, the organization of drainage basins is essentially hierarchical. Even a food chain, a network of dominance and dependence among living organisms, has territorial hierarchy.

2 In intermodal container transportation we talk of the hierarchy of global carriers, regional carriers and local carriers which perform services at the corresponding geographical scale for which they are named. Much has been written about the globalization of containerisation and the development of global networks of container services operated by alliance carriers (Fremont and Soppé, 2003; Midero and Pitto, 2000; Slack, Comtois and McCalla, 2002). Less has been said about the organization of container transportation at the regional level, although Robinson (1998) is an exception in the Asian context and there is literature on container shipping in the Europe (Heaver et al., 2000; 
Notteboom and Winkelmans, 2001) and the Mediterranean (Genco and Pitto, 2000). Robinson's work is a major stimulus for this paper.

3 A subject of interest, and one which fits into the theme of this paper with its emphasis on hierarchical structure, is the development of hub and spoke service networks (O'Kelly, 1998). In such networks there is dominance and dependence among places. The relationships are hierarchical. In terms of spatial arrangement hubs have mainline connections to/from other hubs as well as feeder services to/from themselves. Robinson (1998) speaks of different orders of connections among ports (hubs) and their services. He postulates three phases in the development of container services within a regional setting. At the first phase prior to containerisation many small liner/break bulk companies serve many ports in no discernable hierarchical way. As containerisation is introduced and volumes increase between selected ports, a hub and spoke system begins to emerge with hub ports acting as "articulation" points between mainline and feeder services. Finally, in the third phase a hierarchical network of $1^{\text {st }}, 2^{\text {nd }}$ and $3^{\text {rd }}$ order nets develops based on volumes, costs and efficiencies of operation. The higher the order the greater the values associated with these measures. "Typically, higher order nets will have fewer ports than lower order nets" (Robinson, 1998).

Following Robinson's suggestion and the hierarchical concept applied to transportation networks one would expect that not only would there be fewer ports in high order nets, but also that there would be a limited number of connections among those ports. But, the geographical area served by the high order nets would be larger than the area served by lower ordered nets. In other words, high order nets may be global in scope with limited number of hubs and limited number of connections among them compared to lower order nets. As we move down the hierarchy the geographical area served gets smaller but the number of ports and connections increases. To a degree Robinson shows these expectations in phase three of his model (reproduced in Figure 1). The exception is the geographical scale served by the different nets. First order nets do not serve larger geographical areas than lower order nets, but this can be explained by the fact that Robinson is working in the regional context of Asia and not a global one. 
Figure 1. Phase 3 of Hierarchical Port/Shipping Network Development.

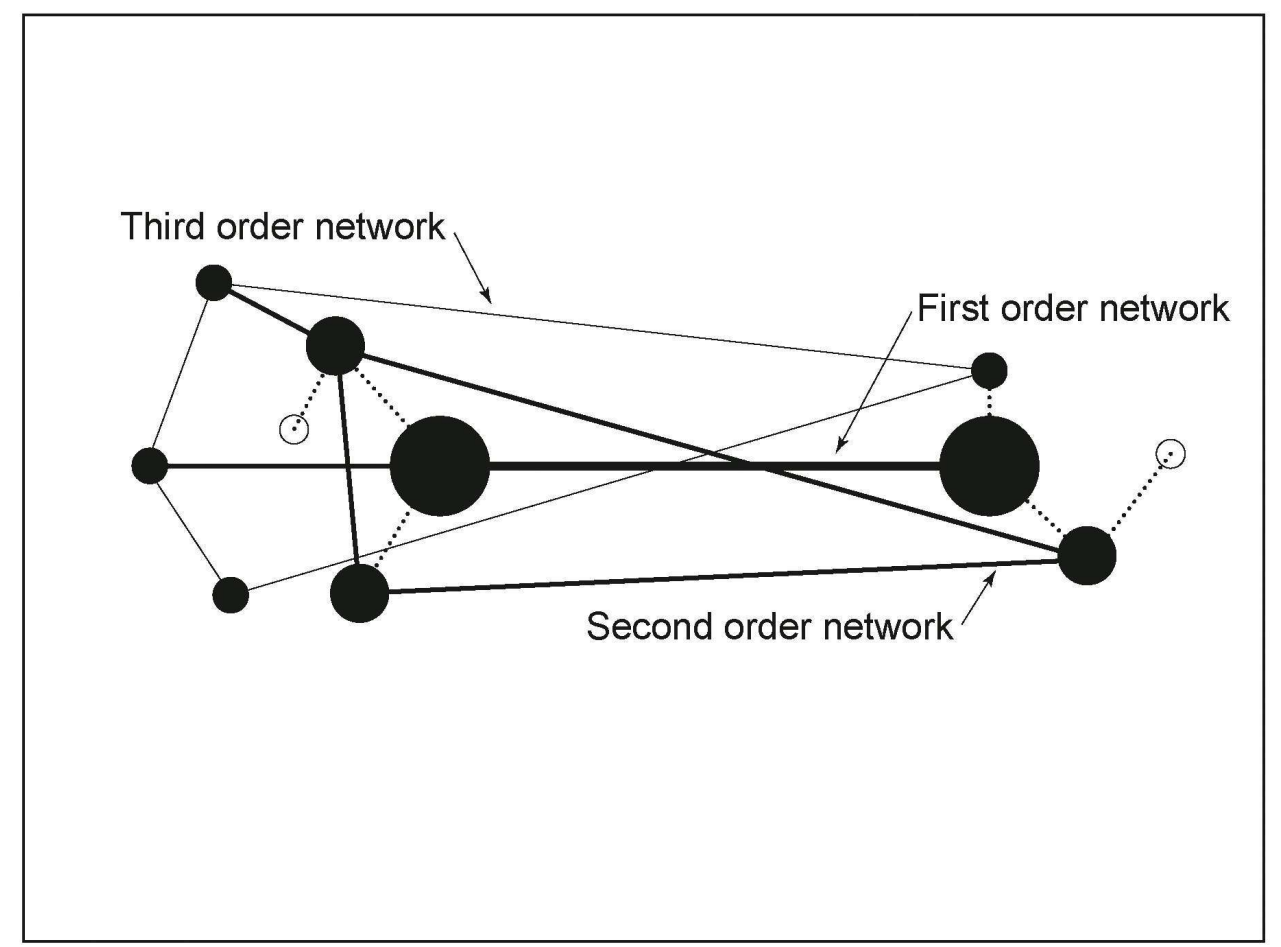

AFTER ROBINSON, 1998

5 How do we see if these expectations are real? There are several necessary data required including, most importantly, ports with their container handling throughput and shipping services among the ports. It would be necessary to define the order of the ports and their networks based not just on throughput volumes, but also on cost and efficiency. It is possible to find out volume throughputs of ports, it is possible to construct service networks of shipping lines, but it is not easy to discover costs or efficiencies of either shipping lines or ports. Thus, defining the order of nets based on Robinson's criteria is problematic. It is, however, possible to define service networks of global, regional and local carriers and have each of these networks serve as surrogates for Robinson's hierarchically ordered networks. Global carriers would operate at the $1^{\text {st }}$ order net level linking major hub ports. Regional carrier operations would define a $2^{\text {nd }}$ order network with calls to hub ports in the $1^{\text {st }}$ order network but also to calls to smaller less efficient ports. Finally, local carriers would act as feeders for both the regional and global hub ports and serve the smallest least efficient ports. This paper investigates whether ordered networks defined in this way will have characteristics postulated above associated with Robinson's hierarchically ordered networks. To reiterate, the expectations are: the higher the order of the network the fewer the ports, the fewer the connections among those ports, but the greater the geographical scale served by the net.

6 To make the investigation manageable it is necessary to limit the geography of the analysis. To contemplate defining networks of global, regional and local carriers at the world scale is daunting. For simplicity, our geographical focus is the Caribbean Basin. 


\section{Container shipping services in the Caribbean basin}

7 The Caribbean basin consists of the Caribbean Sea and the Gulf of Mexico. It has a total surface area of almost 4.5 million $\mathrm{km}^{2}$. There are 33 countries that are either wholly within the basin as islands (23 nations) or have substantial coastlines adjacent to the waters. The latter include the Unites States and Mexico, all the countries of Central America except El Salvador, and the South American countries of Colombia and Venezuela. In total there is approximately $56,000 \mathrm{~km}$ of coastline. The Caribbean is a semi-enclosed sea at the entrance/egress to one of the shipping world's great focal points: the Panama Canal through which most, if not all, of the major container shipping lines pass.

8 A description of container shipping services in the Caribbean basin for 2002 follows. The source of information is the Containerisation International Yearbook (2002).

9 All the shipping line services operating in the Caribbean were recorded for 2002. In the Yearbook Caribbean and/or Central American services are recorded as linking basin ports to 16 different world regions. For this analysis, these regions are collapsed to three: IntraBasin, Americas (North and South) and Inter-Oceanic (the rest of the world). This geographical grouping goes from local to regional to global scale. For Intra-Basin services, only ports in the basin are served. For the Americas' services, ports in the basin and in North or South America are served. Inter-Oceanic services serve not only ports in the Caribbean basin and maybe the Americas but also, more importantly, ports on other continents. For every service listed the shipping company, the ships assigned to the service, their capacity, the frequency of the service and the Caribbean ports of call were recorded. By knowing the ports of call, service networks could be constructed. In order to make these networks it was assumed that ships called at ports in their geographical order of proximity since the Yearbook is not clear on the actual routes ships follow. The service routes were not closed; that is, once the route was drawn, the last port of call was not linked back to the first. For example, if a route included the ports of New Orleans, Houston, Veracruz and Kingston a path was drawn joining those ports in that order but the connection between Kingston and New Orleans was not made. Some service routes just stopped at one port in the Caribbean e.g. Freeport, Bahamas or Puerto Manzanillo, Panama. In these cases the route is represented by a line joined to the port but not joined to any other port either in the Caribbean or beyond. For Regional and Inter-Oceanic services, only the Caribbean ports of call and connections among those ports were shown. Where the service called outside the Caribbean was not recorded. A GIS was used to record and show the Caribbean ports and the service routes.

Figures 2, 3, 4, 5 and 6 show the various networks. Figures 2 and 3 show the same network structure, but in Figure 3 and subsequent networks the land has been removed for simplicity. Figures 2 and 3 show all container shipping services in the Caribbean basin not differentiated by the three geographical groupings. Figure 4 shows only Intra-Basin connections. Figure 5 shows the Caribbean network of Americas' (regional) services. Figure 6 is the Inter-Oceanic connections' network of Caribbean services. Table 1 gives a quantitative summary of the different network characteristics. 
Table 1 . Caribbean Basin Networks' Characteristics.

\begin{tabular}{lcccc} 
& $\begin{array}{c}\text { All Connections } \\
\text { Network } \\
\text { (Fig. 3) }\end{array}$ & $\begin{array}{c}\text { Intra-Basin } \\
\text { Network } \\
\text { (Fig. 4) }\end{array}$ & $\begin{array}{c}\text { Americas' } \\
\text { Network } \\
\text { (Fig. 5) }\end{array}$ & $\begin{array}{c}\text { Inter-Oceanic } \\
\text { Network } \\
\text { (Fig. 6) }\end{array}$ \\
\hline Services & 215 & 40 & 77 & 98 \\
Ports & 88 & 60 & 64 & 50 \\
Links & 564 & 184 & 178 & 222 \\
Connectivity & & 3.06 & & 4.44 \\
(Links/Ports) & 6.41 & & & \\
\hline
\end{tabular}

Figure 2. Caribbean Container Shipping Network (with land), 2002, All Services.

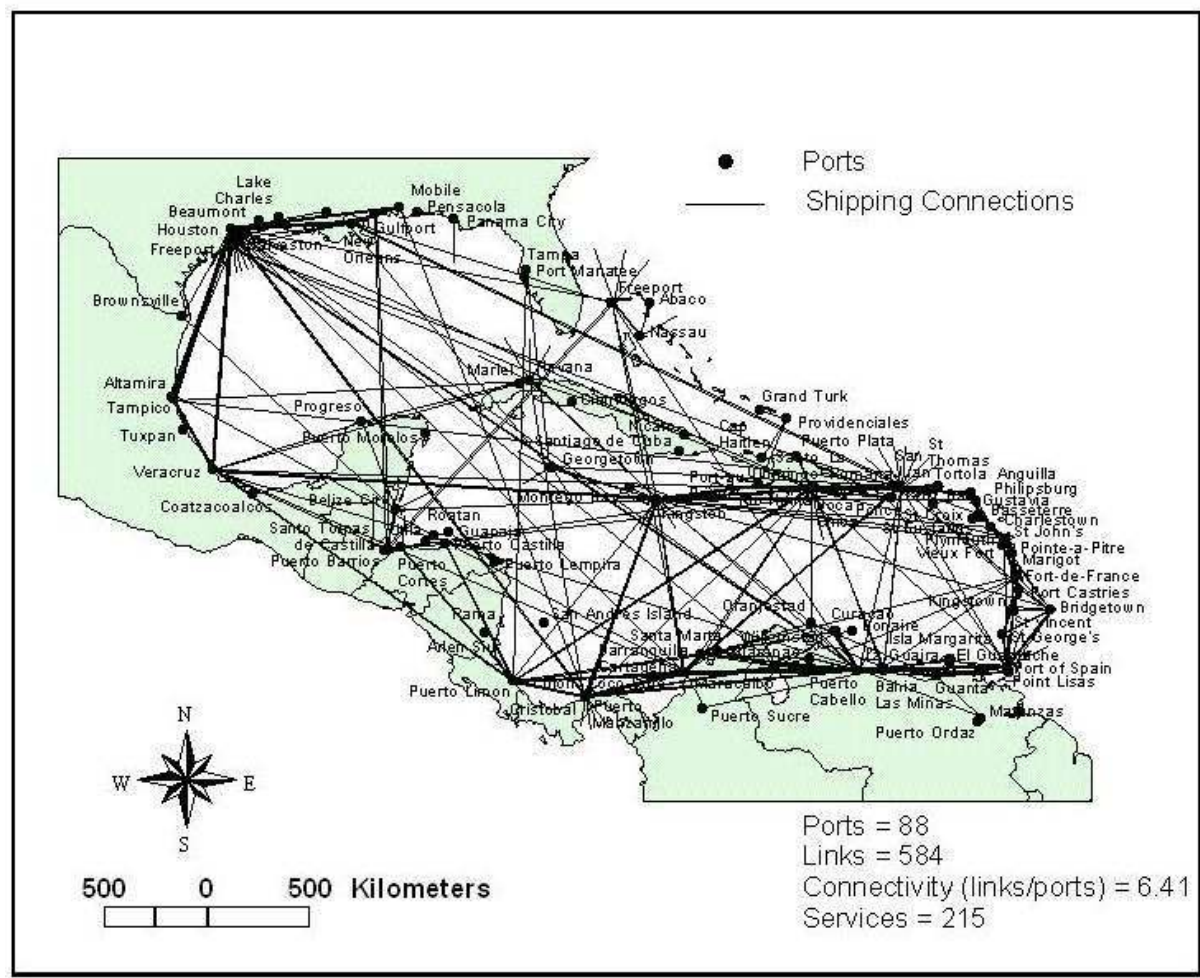


Figure 3. Caribbean Container Shipping Network, 2002, All Services.

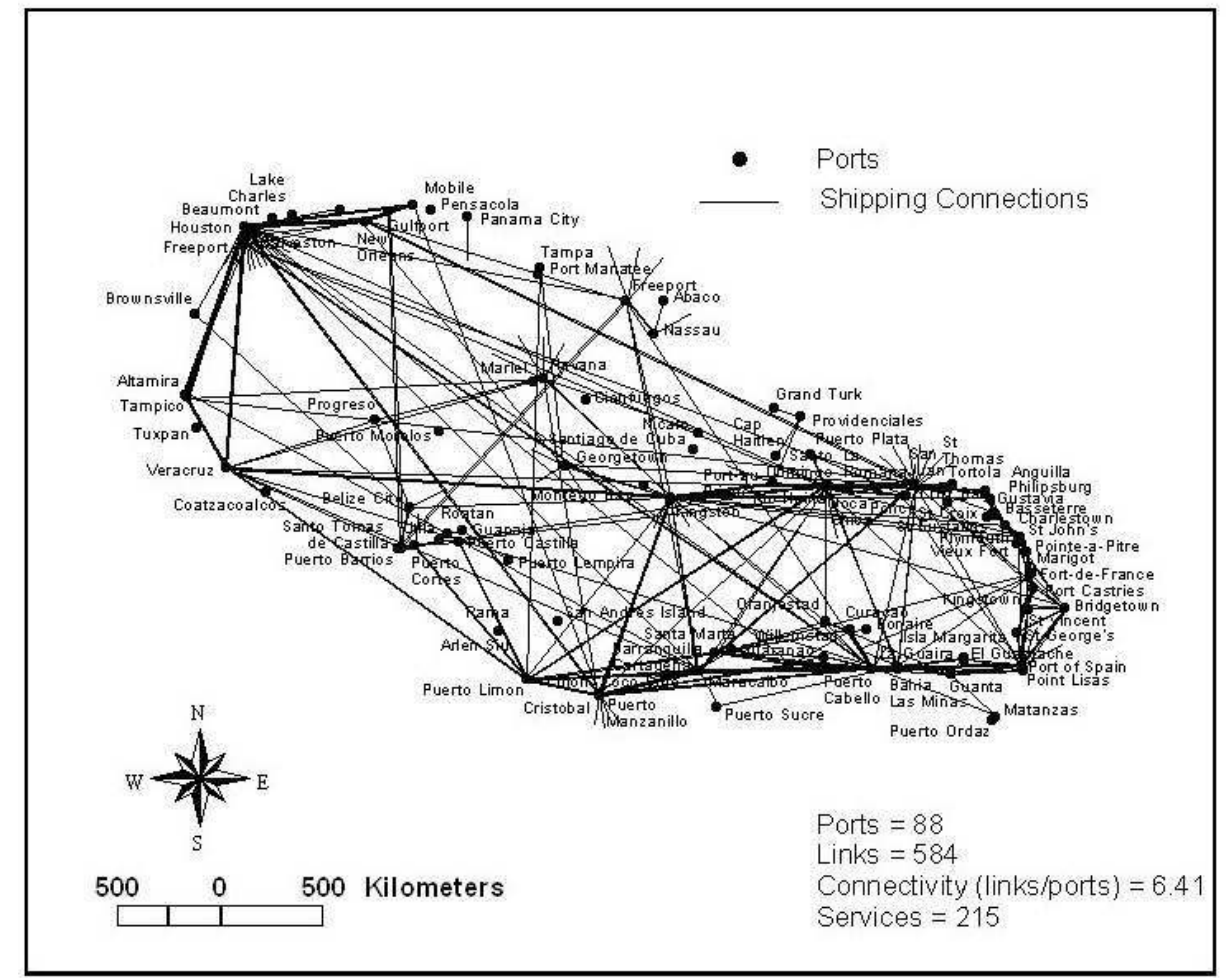

Figure 4. Caribbean Container Shipping Network, 2002, Intra-Basin Services Only.

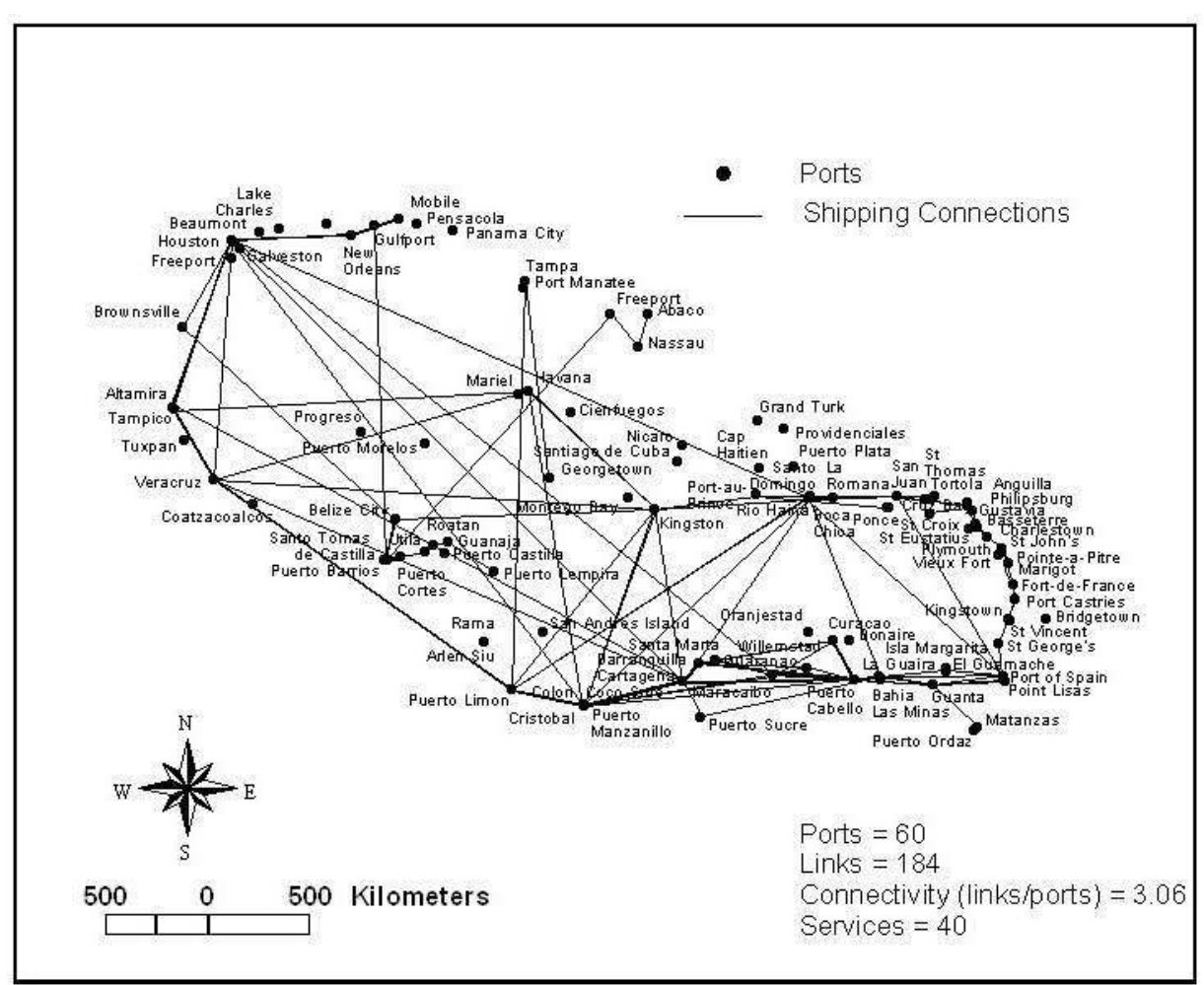


Figure 5. Caribbean Container Shipping Services, 2002, Americas' (Regional) Services Only.

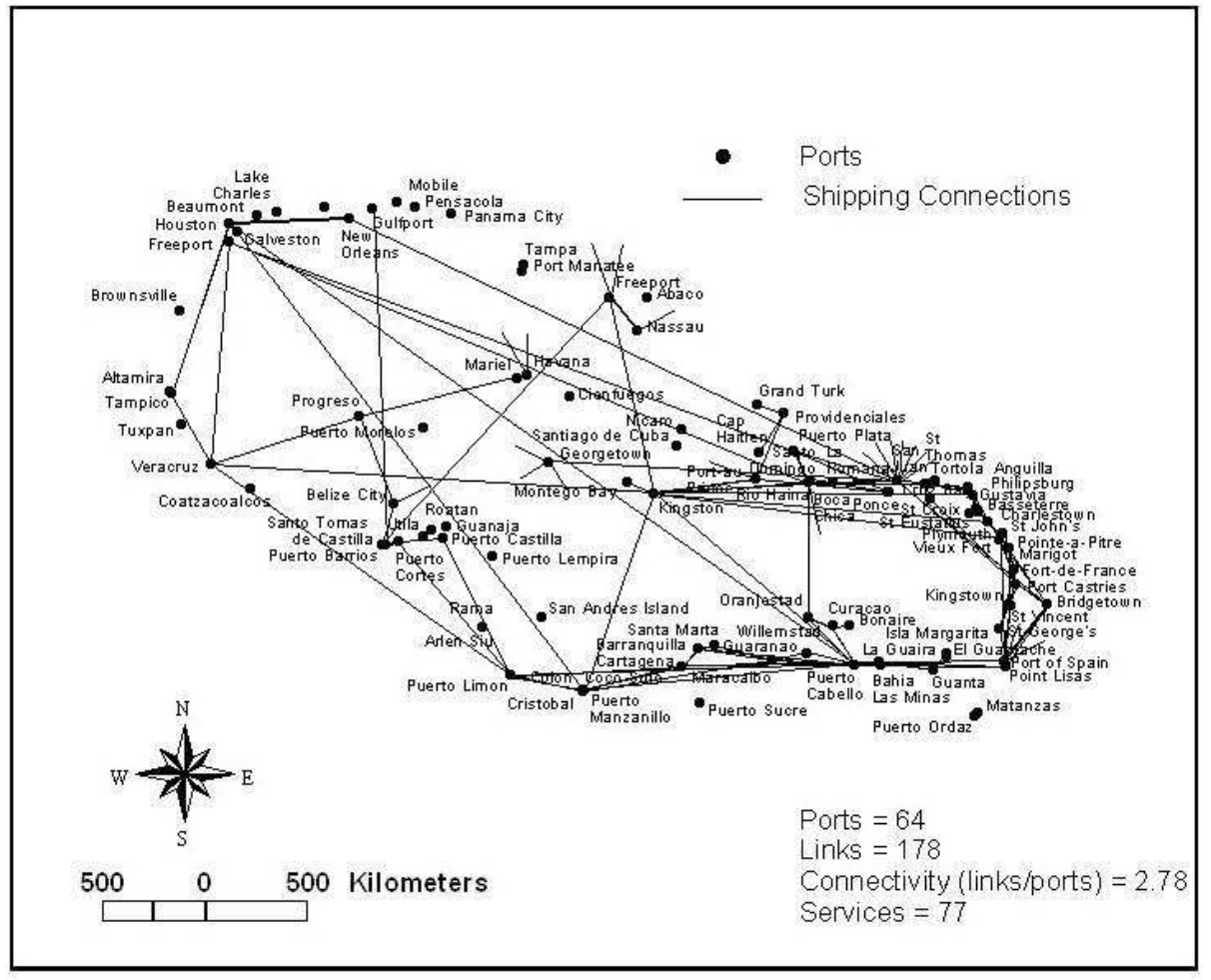

Figure 6. Caribbean Container Shipping Network, 2002, Inter-Oceanic Services Only.

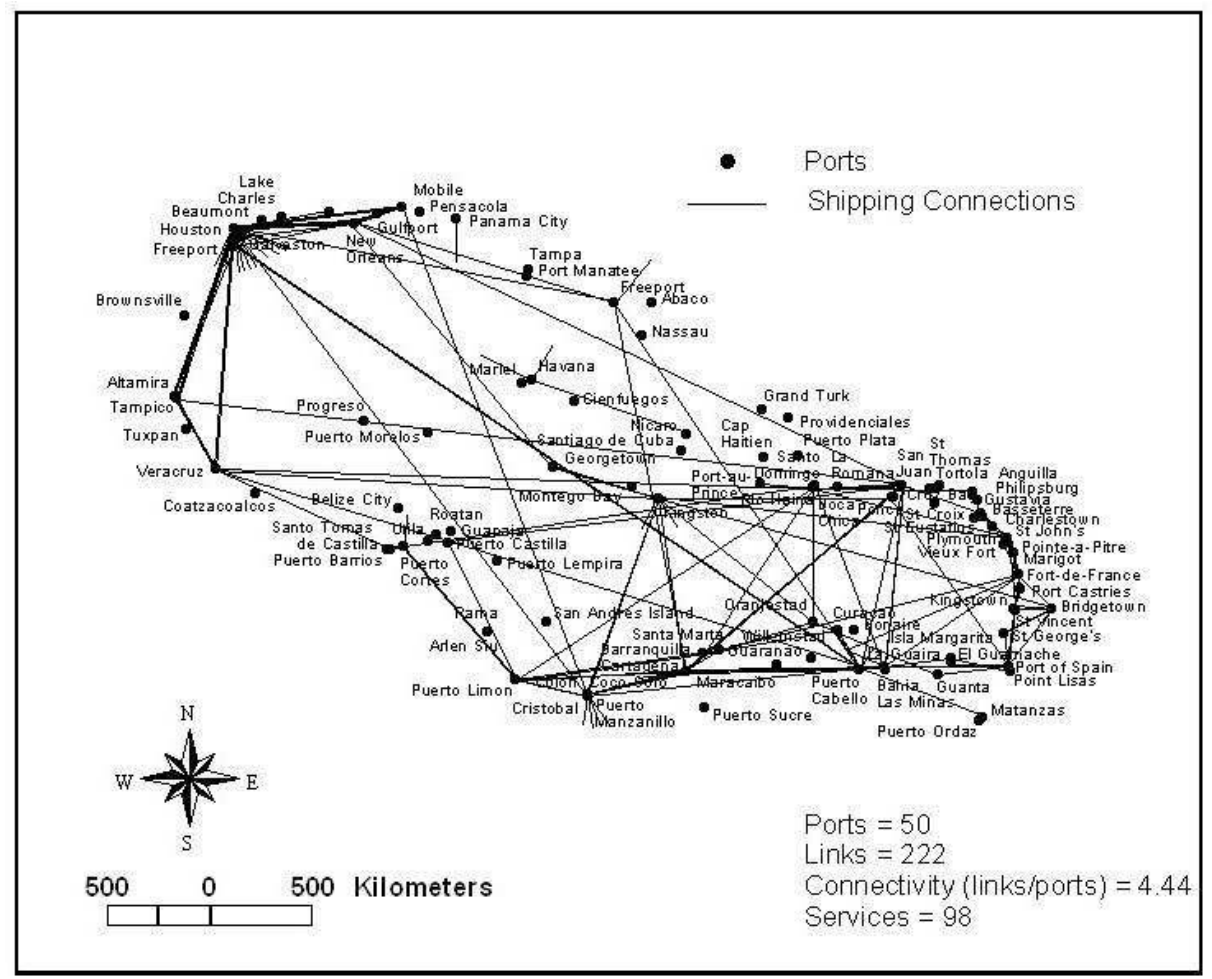

11 The first observation is the complexity of all the networks. Overall, there are 215 different shipping services in the Caribbean basin in 2002 serving 88 different ports with 584 
linkages among the ports (Figure 3). This leads to a highly redundant network with a connectivity measure (links/ports) of 6.41. The redundancy can be seen in the number of connections between different ports. For example, there were 27 services between New Orleans and Houston; 25 between La Guaira and Puerto Cabello (Venezuela) and 15 between La Guaira and Cartagena (Colombia).

Each one of the geographical groupings of networks (global, regional, local) is also highly complex, but the simplest one, in terms of connectivity, is the Americas' regional network with a connectivity of 2.78. The Inter-Oceanic global network has the most services with the most links, but the fewest Caribbean ports served. As a result connectivity is very high (4.44). The Intra-Basin local network has the fewest services but the network serves 60 of the 88 ports. There are more links in the Intra-Basin network than in the Americas' one, but not as many as in the Inter-Oceanic.

There would seem to be little hierarchical ordering evident in the networks. It was expected that as the geographical scale of the services increased (moving up through the hierarchy) there would be fewer ports with fewer connections. The only evidence to support this expectation is the number of ports served at the three geographical scales. The fewest ports are served by the Inter-Oceanic services, the largest geographical scale. On the other hand, there are more links at the Inter-Oceanic scale and more services at that scale than in the other smaller scales. It would seem that as the geographical scale increases the network structure is not getting simpler; it is getting more complex.

To highlight the difficulty of identifying hierarchical network structure Table 2 is presented. It shows the distribution of ports by the networks they belong to. As can be seen $33(37.5 \%)$ of the 88 ports belong to all three networks. These ports are receiving some ships that operate solely within the Caribbean Basin, but they are also receiving ships on regional Americas' services and on Inter-Oceanic services. It is understandable why Houston, Kingston, San Juan, Puerto Manzanillo, or Ria Haina, all of which operate as hubs in the Caribbean (Frankel, 2002) would be part of all the networks, but what can explain the inclusion in the list of Basseterre, Philipsburg or Willemstad, all of which are small island ports not operating as hub centres? Moreover, the five ports that are uniquely part of the Inter-Oceanic network (Baton Rouge, Galveston, Newcastle, Nicaro and Panama City (Florida)) are not major shipping centres.

Table 2. Ports and their Networks.

\begin{tabular}{c|ccc|ccc}
$\begin{array}{c}\text { Number of ports } \\
\text { belonging to all 3 } \\
\text { networks }\end{array}$ & \multicolumn{3}{|c|}{$\begin{array}{c}\text { Number of ports } \\
\text { belonging to 2 } \\
\text { networks }\end{array}$} & $\begin{array}{c}\text { Number of ports } \\
\text { belonging to 1 } \\
\text { network }\end{array}$ \\
\hline & $\begin{array}{c}\text { Intra- } \\
\text { Basin and } \\
\text { Americas }\end{array}$ & $\begin{array}{c}\text { Intra-Basin } \\
\text { and Inter- } \\
\text { Oceanic }\end{array}$ & $\begin{array}{c}\text { Americas' } \\
\text { and Inter- } \\
\text { Oceanic }\end{array}$ & $\begin{array}{c}\text { Intra- } \\
\text { Basin }\end{array}$ & Americas' & $\begin{array}{c}\text { Inter- } \\
\text { Oceanic }\end{array}$ \\
\hline 33 & 8 & 6 & 6 & 13 & 17 & 5
\end{tabular}

\section{Discussion}

It is obvious that the expectations of hierarchical ordering are not clearly evident in the analysis. The global carrier network, an assumed surrogate for Robinson's $1^{\text {st }}$ order 
network, is not much different from the regional carriers' network or the local carriers' one. The hierarchy of networks that Robinson suggests is not to be found in the geographical extent of the carriers' operations. The hierarchy is not geographically service-based.

Why would there be similarly configured networks of global, regional and local carriers operating in the Caribbean basin? Only a small proportion of container shipping in the Caribbean basin is dedicated to the basin itself, the majority is to link the basin ports to markets outside the basin. Why?

There are two explanations offered. First, there is the rationale to have container services in the Caribbean in the first place. The most important economic trading connections trade links - for the islands and ports of the Caribbean are to the world beyond the basin, not internally within the basin. In fact, the islands have relatively little to trade with each other given that many have the same physical environment. There is a need for connections to mainland US ports, for example, or to South American ports but many of these links are to ports outside the basin and show up on the Americas' network. It is incorrect to think that there is a need for many trade links at the smallest geographical scale and fewer links to places outside the basin. Rather the need is to have many trade links at the regional and global scale. Furthermore, the more direct these links are the better.

The second explanation lies in the service strategies of shipping lines. Some of the lines operating in the Caribbean are the biggest and most efficient in the world - MaerskSealand, Hapag-Lloyd, OOCL, APL, P\&O Nedlloyd, etc. Others are small inter-island carriers (Caribbean General Maritime, Inter Island Ro Ro) and presumably not as efficient given the lack of economies of scale. The very large global carriers are not just operating at the Inter-Oceanic level, though. They also have services at the other two levels. They may be global carriers, but they are also regional and local carriers. For example, MaerskSealand offered 21 services to, through and within the Caribbean basin in 2002 (Figure 7). Ten were Inter-Oceanic, 10 were Americas' connections and one was devoted to the basin itself. Similarly, of the 20 services offered by shipping lines in the Grand Alliance two were Intra-Basin, four were Regional and 14 were Inter-Oceanic. The majority of shipping lines operates what might be termed one path but multi-port ("mail carrier") services through the Basin. They are not trying to differentiate an Intra-Basin service or an Americas' service or an Inter-Oceanic service; they are offering services that do all three at once. Maersk-Sealand uses Puerto Manzanillo in Panama, Rio Haina in the Dominican Republic, Freeport, Bahamas and Houston as hubs in the Caribbean, but many of the ships stopping at these places are also stopping elsewhere in the basin and continuing out of the basin. 


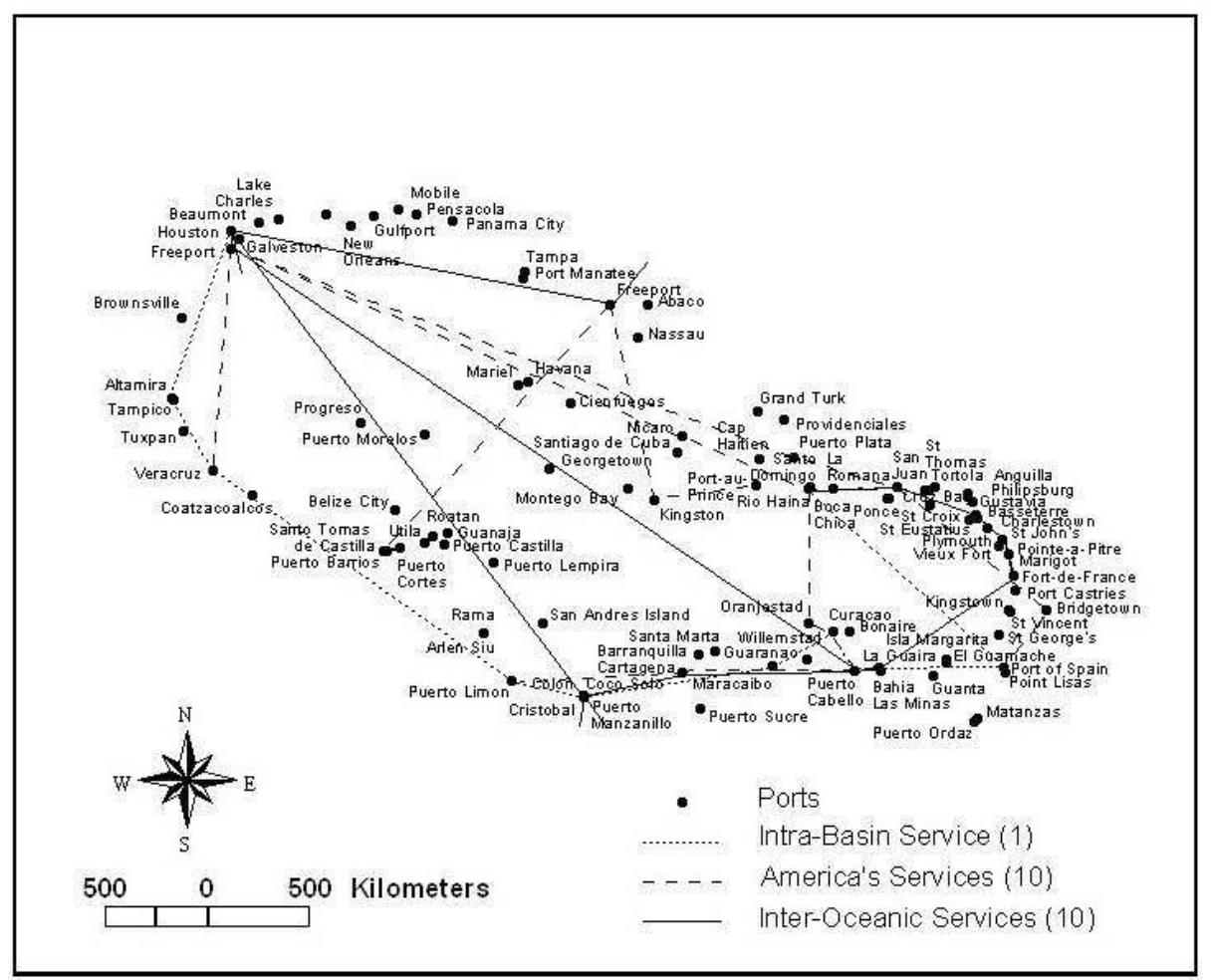

The network configuration shows the hub-and spoke network concept does not operate well in the Caribbean basin. If it did, there would be far more Intra-Basin services and fewer Americas' and Inter-Oceanic services, with the Inter-Oceanic services focused at a few major hub ports. From these hubs there would be regional and local feeders outnumbering the Inter-Oceanic services. The evidence does not show this arrangement. For example, Kingston and Rio Haina, both acknowledged hub ports in the Caribbean, do not show much differentiation among the types of services found at them. As Table 3 shows neither port has a significant number of services at the Intra-Basin level which are different than the number of services at the other levels. At Kingston, for example, there are just as many local services as global ones. Rio Haina does show an increasing progression of services with decreasing scale, but the numbers are very similar at all levels.

Table 3. Number of Services at Kingston and Rio Haina According to the Network to which They Belong.

\begin{tabular}{lcc}
\hline & Kingston & Pio Haina \\
\hline Intra- Basin Network & 8 & 10 \\
Americas' Network & 11 & 9 \\
Inter-Oceanic Network & 8 & 7 \\
\hline TOTAL & 27 & 26
\end{tabular}




\section{Conclusion}

There is not a regional carriers' network nested within the global, nor is there a local network nested within the regional and global carriers' networks. There is much overlap among the networks. It may be that Robinson's $1^{\text {st }}$ order, $2^{\text {nd }}$ order and $3^{\text {rd }}$ order nets exist in the Caribbean but they are not defined by the geographical extent of the services offered by the carriers. To discover their existence requires data not available to this investigation.

What can we learn from the network structures isolated?

First, there is a great deal of complexity and redundancy in each of the networks. The most redundant, and therefore competitive, network is the Inter-Oceanic one.

Secondly, many ports belong to all three nets, and shipping companies offer services on more than one level. A major question to ask is: if the largest and most efficient global carriers are operating services at all geographical scales, what is their impact on the smaller less efficient services at the regional and local geographical scales? If Robinson is correct that large efficient carriers operate at $1^{\text {st }}$ order nets, then their operations at lower order nets must be a threat to other carriers at these levels. The data in this paper do not permit an investigation of this suggestion, but certainly further research is warranted along these lines.

Thirdly, hub-and-spoke service patterns are not immediately obvious.

25

Finally, the idea of dominance and dependence among container shipping services, although valid conceptually, has been difficult to show empirically with container shipping operation in the Caribbean. It would appear that the sought-after hierarchy is not based on the geographical reach of the services. Services are offered at all levels, geographically, but how they are linked in a predominance relationship requires further inquiry.

\section{BIBLIOGRAPHY}

CONTAINERISATION INTERNATIONAL YEARBOOK (2002), London, National Magazine Company.

FRANKEL E.G. (2002), “The challenge of container transshipment in the Caribbean”, paper presented at International Association of Maritime Economists (IAME) Conference, Panama, 13-15 November 2002.

FRÉMONT A., SOPPÉ M.(2003), “The service strategies of liner shipping companies”, paper presented at the research seminar, Maritime Transport, Globalisation, Regional Integration and Territorial Development, Le Havre, France, 3-5 June 2003. 
GENCO P., PITTO A. (2000), “Transhipment and liner networks restructuring: opportunities and threats for Mediterranean ports", paper presented at International Association of Maritime Economists (IAME) Conference, Naples, Italy, 13-15 September 2000.

HEAVER, T., MEERSMAN H., MORGAN F., VAN DE VOORDE E. (2000), “Do mergers and alliances influence European shipping and port competition?", Maritime Policy and Management, 27, pp. 363-73.

MEDDA F., NIJKAMP P., RIETVELD P. (2000), "Hierarchies of spatial network systems", in BUETHE M., NIJKAMP P. (eds.), New Contributions to Transportation Analysis in Europe, Aldershot, Ashgate, pp. 151-169.

MIDORO R., PITTO A. (2000), “A critical evaluation of strategic alliances in liner shipping”, Maritime Policy and Management, 27, pp. 31-40.

NOTTEBOOM T. WINKELMANS W. (2001), “Consolidation and contestability in the European container handling industry", paper presented at International Association of Maritime Economists (IAME) Conference, The Hong Kong Polytechnic University, 18-20 July, 2001.

O'KELLY M. (1998), “A geographer's analysis of hub and spoke networks”, Journal of Transport Geography, 6, 3, pp. 171-186.

ROBINSON R. (1998), “Asian hub/feeder nets: the dynamics of restructuring”, Maritime Policy and Management, 25, pp. 21-40.

SLACK. B., COMTOIS C., MCCALLA R. (2002), "Strategic alliances in the container shipping industry: a global perspective", Maritime Policy and Management, 29, pp. 65-76.

\section{ABSTRACTS}

This paper concerns the network structure of container shipping services in the Caribbean Basin. It investigates Robinson's (1998) concept of hierarchical networks in container shipping in which the higher the order of the network the fewer the ports and the fewer the connections among those ports. Three networks are defined based on the geographical reach of the carriers' services: Intra-Basin, Americas' region, and Inter-Oceanic. All three networks are quite similar, although there are differences in the number of ports served and the number of services and linkages among the ports of each net. Each net has a high degree of redundancy. Almost 40 per cent of the 88 ports in the basin belong to all three nets. It is not true that the higher the order the network, where order is defined by the geographical scale of service, the fewer ports and the fewer linkages. Defining hierarchical structure is elusive. Even the hub and spoke service structure is not immediately obvious.

Cet article concerne la structure de type réseau des services de transport maritime des conteneurs dans le Bassin des Caraïbes. Il étudie le concept des réseaux hiérarchiques de Robinson (1998) appliqué au transport maritime des conteneurs, où si l'ordre du réseau est plus haut, le nombre des ports et le nombre des connexions entre ces ports sont plus petits. Du point de vue de l'étendue géographique des itinéraires des transporteurs, on définit trois réseaux: Intra-Bassin, la Région des Amériques, et Inter-Océanique. Ces trois réseaux sont tout à fait semblables, bien qu'il y ait des différences dans le nombre des ports servis et celui des services ou des connexions entre les ports de chaque réseau. Chaque réseau possède un degré élevé de redondance. Presque $40 \%$ des 88 ports du bassin appartiennent à chacun des trois réseaux. Il n'est pas vrai que si l'ordre du réseau est plus haut - où l'ordre est défini par l'échelle géographique du service - le nombre des ports et celui des connexions entre les ports sont plus 
petits. Définir la structure hiérarchique est quelque chose d'évasif. Même la structure des services du type moyeu et rayons n'est pas évidente.

INDEX

Keywords: hierarchy, networks, intra-basin, Americas, inter-oceanic, hub and spoke, Caribbean, container shipping

Mots-clés: hiérarchie, réseau, intra-bassin, les Amériques, inter-océanique, moyeu et rayons, Caraïbes, transport des conteneurs

\section{AUTHOR}

ROBERT J. MCCALLA

Department of Geography, Saint Mary’s University, Halifax, NS, Canada, robert.mccalla@smu.ca 